
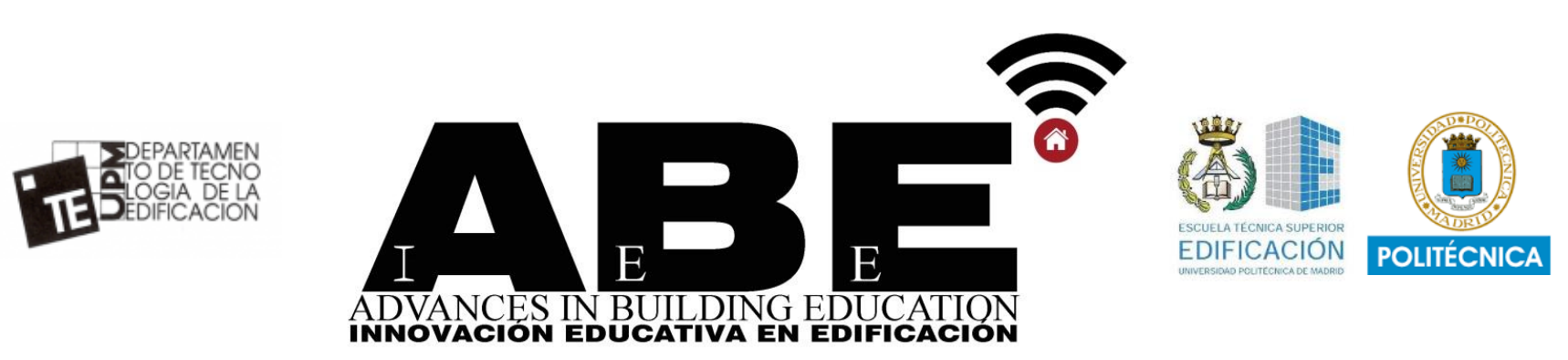

\title{
Virtual environments of teaching-learning for training in experimental techniques. Innovation in multidisciplinary groups
}

\author{
$M^{a}$ Paz Sáez Pérez ${ }^{1 *}$, Kerstin Kelert ${ }^{2}$, Carlos Rodríguez-Navarro ${ }^{3}$, Encarnación Ruiz Agudo ${ }^{4}$, Aurelia Ibáñez \\ Velasco ${ }^{5}$, Carolina Cardell Fernández ${ }^{6}$, María del Rosario Blanc García ${ }^{7}$, Giuseppe Cultrone ${ }^{8}$, Pedro Bel Anzue ${ }^{9}$ \\ ${ }^{1 *}$ Departamento de Construcciones Arquitectónicas. E.T.S. Ingeniería Edificación. Universidad de Granada mpsaez@ugr.es \\ ${ }^{2}$ Departamento de Mineralogía y Petrología. Facultad de Ciencias. Universidad de Granada kelert@ugr.es \\ ${ }^{3}$ Departamento de Mineralogía y Petrología. Facultad de Ciencias. Universidad de Granada carlosrn@ugr.es \\ ${ }^{4}$ Departamento de Mineralogía y Petrología. Facultad de Ciencias. Universidad de Granada encaruiz@ugr.es \\ ${ }^{5}$ Departamento de Física Aplicada. Facultad de Ciencias. Universidad de Granada aureliaiv@ugr.es \\ ${ }^{6}$ Departamento de Mineralogía y Petrología. Facultad de Ciencias. Universidad de Granada cardell@ugr.es \\ ${ }^{7}$ Departamento de Química Analítica. Facultad de Ciencias. Universidad de Granada mrblanc@ugr.es \\ ${ }^{8}$ Departamento de Mineralogía y Petrología. Facultad de Ciencias. Universidad de Granada cultrone@ugr.es \\ ${ }^{9}$ Departamento de Mineralogía y Petrología. Facultad de Ciencias. Universidad de Granada pedro.bel.anzue@gmail.com
}




\section{HIGHLIGHTS}

- The incorporation of virtualization in the experimental techniques teaching

- Improvements in the teaching-learning process in multidisciplinary groups

- Acquisition of skills and professional development

- Technological resources in innovation, improvement of teaching and its goals

\section{ABSTRACT}

In this research, through the development of a teaching innovation project, the aim is to highlight the importance of educational and pedagogical changes that require both the adaptation of teaching to new situations and the possibility of taking advantage of the available resources to be applied in different degrees (master and degree) simultaneously.

For this, the innovation experience carried out by a group of professors from the University of Granada who teach subjects in the CiTPA Master, MARA Master and Degree in Conservation and Restoration of Cultural Assets is presented. It addresses the development of unpublished teaching material (videos, manuals for the application of analytical techniques and the use of specialized software, all in a bilingual version), for its integration into different subjects in which it is necessary to make different research techniques known, use of specific software and precise operational activities that are used for the characterization of materials.

Competency-based learning through innovation offers students a real and applied experience that has an immediate practical and professional implication, taking advantage of the skills of the new generations. The results, expected in future evaluations, must be analyzed both individually and for the group of subjects, being recognized in advance the good result and the facilities that teamwork, the recognition of skills and the facilities entail in the field of the teacher, the selection of common competences between different subjects and training levels.

Keywords: technological resources, experimental research techniques, educational innovation, multidisciplinary experience, skills.

\section{INTRODUCTION}

Competency-based teaching-learning models have been included in the last decades in Higher Education to creatively and dynamically face the changes and new proposals in the education of students, through the use of new technologies, thus achieving the improvement of teaching quality.

For this, innovation has been consolidated as the best strategic line in university policies promoting educational change, problem solving, improvement in student training processes and specific training of university teachers.

The implementation of the EHEA represented a change of great importance for higher education institutions, moving the training processes towards the learning processes by competences [1], its fulfillment implied the review of the references and the implementation and promotion of innovative teaching experiences learning by incorporating new didactic strategies using the resources offered by ICT and generating the distribution of materials, all of this 
through the institutionalization of improvement and innovation plans that were launched by the different universities.

In the historical moment in which we live, the contribution of new alternatives and innovative experiences with respect to the conventional teaching-learning process, as well as the inclusion of technological resources and the use of information technologies, are of fundamental interest.

In fact, keeping students at different educational levels sufficiently motivated is a major challenge, even for more experienced teachers.

The innovation project that is presented aims to achieve in part the motivation of students through the visualization of topics that interest them and that are important for their training and professional development [2], [3].

The most important competence of the digital age that students must acquire is that of learning to learn. For this reason, since the implementation of the EHEA, learning has gone from being an individual construction of knowledge, to becoming a collective and social process [2]. In this context, competency-based learning is designed to be carried out in a technological environment supported by computer and audiovisual resources.

The idea of responsible learning leads to more personalized, more efficient and more oriented towards the acquisition of competences. For this, flexible methodologies are required, for which the telematic means are optimally adapted, and not only for individual learning, but also for cooperative work [4].

Focused on the context of innovation, according to [5], the word "innovate" is identified with other terms such as "change", "renewal", "transformation", "reform", "modification", which entails a sequence of decisions, a systematic and organized work that generates the innovation proposal that in a broader sense is understood by the same authors as "the art of applying, in new conditions, in a specific context and with a precise objective, the sciences, techniques, and therefore it supposes that the introduction of something new that produces improvement, promotes advances in substantial aspects in the object of innovation ", and in the participating agents (students and teachersteachers).

In the educational context, the term innovation is considered for the planned actions that seek to produce a change in educational institutions, which favors an improvement fundamentally in the development of practices that represent the prelude to the student's professional performance, counting on the acceptance and approval of the educational community.

In this way, teaching innovation allows interaction in all areas and processes of the educational space, such as the centers, departments, laboratories and classrooms and even the institution itself, generating in them the necessary conditions to advance in the improvement of the quality, having to assume in all cases its "permanent, integrating and transforming" character [5].

In a broader sense, educational innovation is considered to be the changes that can be incorporated in the teaching-learning process, applying both to the theoretical, methodological, procedural, evaluation and curricular contents, accepting in all cases the modification of the relationships teacher-student.

Said changes are recognized in the need for commitment and participation of the agents, all of whom are beneficiaries of the results obtained. 
In the case of the group of students, center or focus of attention, they will be the main beneficiaries since the innovation is focused on the acquisition of valid skills throughout life, which will allow them to assume responsibilities in their professional field. For the group of teachers, being the main protagonists, they will be those who play the guiding and facilitating role of knowledge as well as those who manage the use of resources that allow the development of new knowledge, being according to [6] those who focus the capacity to achieve the essential challenges of university excellence. In addition and as confirmed [1], the role of the teacher changes from the transmission of knowledge to a mediator in the construction of their own knowledge [7], [8], [9].

Focused on the learning model, at present, recognized the change of scenery, the use of technologies is not simply a tool of interest for individualized learning but also a support for group learning and the joint creation of knowledge, facilitating with its I use the acquisition of skills necessary for continuous learning.

In the educational field, never like now, after the exceptional situation experienced with COVID19, had a situation been experienced for teachers to integrate technological resources into their teaching designs and practices "without exception". That is why through this study, it is intended to publicize the teaching experience that resorts to the use of teachinglearning systems in virtual environments as a process of affordable innovation, based on the creation of material to develop the ability to learn and adapt, both for teachers and students, thus understanding innovation as a systematic and planned process, thus achieving an improvement in the training and learning process. [1], [10], [11], [12], [13].

In this line, [14] establish the teaching website as the basic vehicle for effective communication that gives access to the set of computer and telematic resources for both learning, as well as for knowledge management and of course for cooperative work between participants in the learning process.

As a whole, all the above, according to [1], constitutes an innovation considering that it is any project that involves the use of technological resources, methodological changes and the training of university professors.

Focusing on the degrees in which the participating teaching team teaches, and analyzing the main needs originated in the context of said degrees, it was confirmed that teaching dedicated to one of the most important and widely used techniques in the characterization of heritage materials historical, X-ray diffraction (XRD), showed that students required additional practical training dedicated to sample preparation and the use of specialized software for the interpretation of the data obtained, recognizing that in the classroom the time available was limited to adequately cover the wide range of analytical techniques in the corresponding subjects.

The previous analysis carried out and the innovation approach proposed offering new and better opportunities for training in skills, through a specific teaching innovation project for these degrees and needs, which will train future professionals in the development of activities and analysis own profession, thereby emphasizing the value of laboratory practices in any of the degrees, to gradually configure the 
professional identity with a teaching approach based on the acquisition of competences.

The plan in which the present teaching innovation project called Plan FIDO UGR [15] of the University of Granada is developed, is included within the basic actions of teacher training, which address the fundamental and necessary aspects for the performance of tasks teachers. As stated in his report this "type of actions are focused on the awareness of teachers towards different aspects related to teaching, the introductory approach of different contents, the theoretical training, the methodological and/or basic didactic development for the exercise of the teaching and the development of teaching materials and practical applications on a certain topic ".

This paper shows the Teaching Innovation Project (PID) [16] entitled "X-ray Diffraction (XRD) - Qualitative and Quantitative Analysis applied to historical heritage materials as The Manual for students of the Master in Science and Technology in Architectural Heritage (CiTPA UGR), Master's Degree in Architectural Rehabilitation (MARA - UGR) and the Degree in Conservation and Restoration of Cultural Assets (UGR) ".

It was developed within the framework of the 2020-2022 call for Innovation and Teaching Improvement Projects, Plan FIDO of the University of Granada (UGR) as any Innovation Project, it arises from the evident need to offer specific training.

In this specific case about the DRX technique so that students can carry out in the Department of Mineralogy and Petrology the characterization of a large number of samples that need to be analyzed, during the development of their TFG / TFMs or scientific publications .
The project can be considered a continuity of two Teaching Innovation Projects prepared by professors from this same PID, specifically: "Use of advanced tools in structural crystallography for students of geology, chemistry, physics and chemical engineering" and "Free distribution computer tools ("Freeware") for the practical teaching of structural crystallography in a virtual environment".

The objective of both projects was, as in this case, to provide tools for the practical training of students in the use of specialized software for the application of X-ray diffraction in the field of historical heritage, facilitating self-learning.

This project focuses on the development of an innovation product, specifically audiovisual and written material, available on a website created for this purpose, which exposes the XRD technique in detail in order to achieve training in skills, emphasizing the promotion of the skills and techniques established in the teaching guides as well as providing content, knowledge and rigor to the development of the activities to be carried out in the laboratory

Focused on competencies, those established in the teaching guides for each degree (see Table 1) are directly related to specific professional competencies, with which students can form an image of the possibilities of expert action within the chosen degree [17], in addition to incorporating technological skills, data collection and interpretation, etc. into its application. [18], [19]. 
Table 1: Competences in the participating degrees Degree of Conservation and Restoration of Cultural Assets (Analysis Techniques II)

Know and select the analytical systems and interpret the results obtained to understand the materiality of the Cultural Asset and guide its intervention.

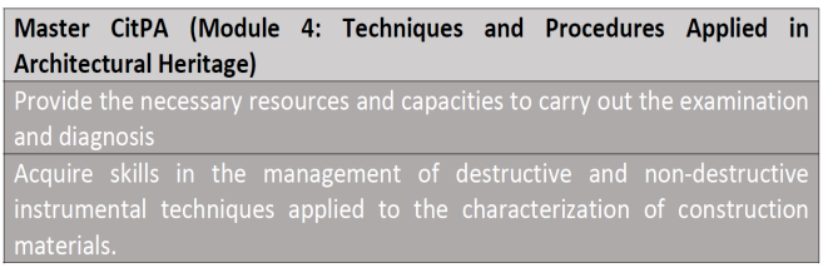

Master MARA (Module 1: Research and documentation techniques in architectural heritage)

On the other hand, the development of the practical sessions also offers during their realization, the opportunity to assume responsibilities and competences both in the process of preparing the material, as well as in the handling and care of the instruments and apparatus. Not forgetting the tasks of managing software and interpreting results.

\section{AIMS}

The aims on which the developed innovation project has been based have been structured into two groups:

\subsection{Plan FIDO UGR aims}

The aims set out in the first group for the actions applicable to this research project are:

- Improve the identification, integration and / or generation of good and innovative teaching practices as a continuous process of improvement.

- Promote research on teaching and the construction of teaching materials, the development of practical applications, and the creation of resources to be shared by the university community and the communication and transfer of knowledge.

- Progress in the digitization and virtualization of teaching in aspects related to its design, management and evaluation.

\subsection{Teaching Innovation Project (PID) aims}

For its part, the main aim of the PID is focused on trying to improve the teaching-learning process based on the acquisition of competencies, taking advantage of the opportunities offered by new learning and knowledge technologies, for students enrolled in the subjects and titles involved.

For this second group, the specific aims are established in a double aspect oriented towards the teacher and the student, being the following:

- Improve the resources available to students to acquire skills in the management of analytical techniques (XRD) applied to the characterization of historical heritage materials.

- Increase interest in the subject by introducing new technologies (specialized software) in the corresponding subjects of the Bachelor's and Master's degrees.

- Improve student performance through practical training adapted to the needs of students, especially in the context of research for the TFG / TFM and future professional activities in the field of historical heritage. 
- Encourage self-learning and self-evaluation through bilingual visual and auditory teaching materials.

\section{METHODOLOGY}

Innovation as a planned methodological system requires the study of all the elements involved through different techniques and instruments [20].

In this case, the first of the instruments is established by the Permanent Training Program for the improvement of teaching established by the University of Granada, in which various training actions organized in different lines and levels are contemplated.

Within the priority lines of action, this project is included in the so-called Dimension 3. Adequacy of teaching and educational innovation to today's society, developing its content in lines 3.1. and 3.4:

- - Line 3.1. Improvement of teaching skills in today's university: Actions to train teachers in adjusting their teaching practices to the requirements of society and the University of the XXI century.

- - Line 3.4. Digitization and virtualization of teaching: Actions to train teachers for digitization, virtualization of teaching and face the challenges of the digital society.

That is why it is a fundamentally practical methodology that welcomes different activities that are developed from collective activity, through team action [21], [22] to end with individual action.

In line with what was stated by [5], the methodological approach is carried out as a systematic process, supported by an established planning in which it is essential to "direct attention" to the needs that arise as a starting point for innovation., the participating agents, the product of said innovation and the evaluation of the process and the results. That is, the techniques of evaluative research are applied [20].

The methodology is always proposed in conjunction with all the teaching participants of the project, which guarantees its proper development and operation during its implementation.

The work plan proposed in the development of the PID and the sequence of activities is shown below, represented in the following figures and tables:

- PID work plan (Figure 1)

- Chronology of the PID Work Plan (Table 2)

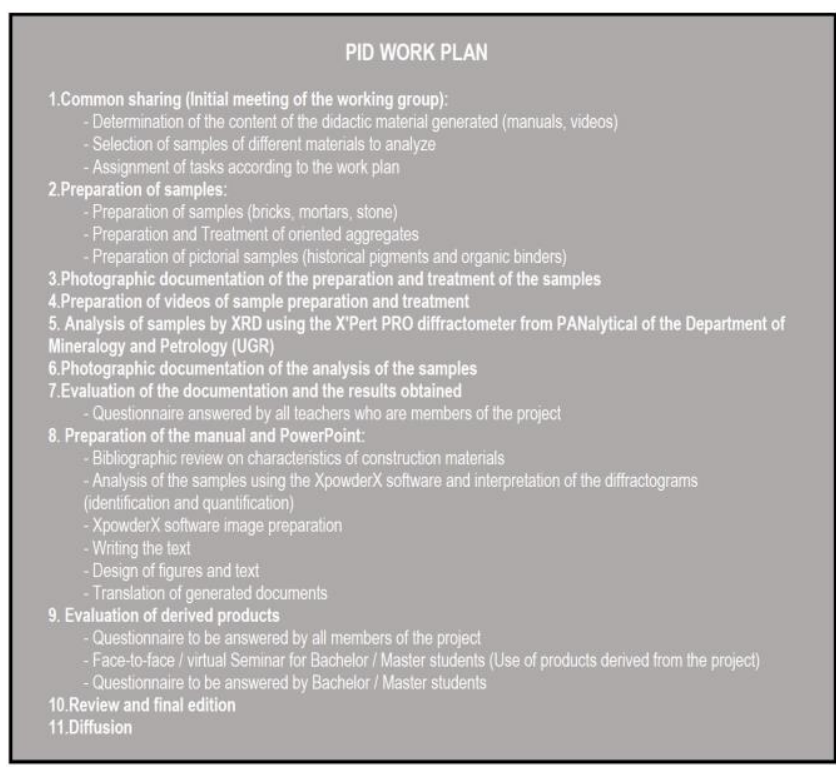

Fig. 1: Work plan developed in the PID

Table 2: Work plan timetable

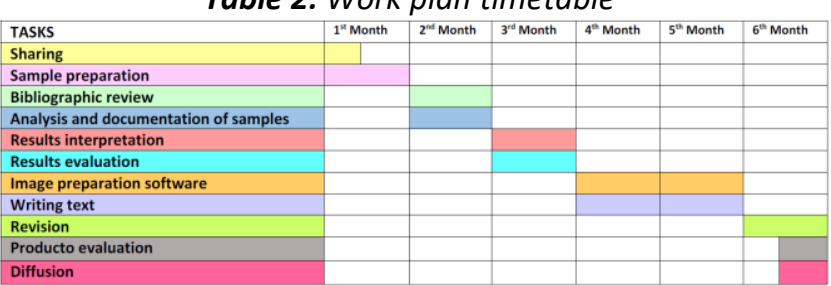


The first action carried out after the initial meeting of the working group consisted in determining the content of the material (product) that would be obtained from the PID. For this, in addition to the content, the subjects in which it was going to be applied were determined and a common format was established for all the videos, manuals and complementary material, so that they included both theoretical explanations and practical development, with an extension and duration appropriate to each content.

Subsequently, the documents generated would be included in a web page and would be classified according to the subject matter in each case. Subsequently, the web link has been made available to all students through the teaching guides of the subjects as well as other websites usually used by them (pages of master's and bachelor's degrees, website of research groups, etc.).

The documents generated during the development of the PID were the following:

Manuals: they addressed content that allowed students to identify basic content to be able to attend the videos properly, correctly interpreting all the processes. The results were compiled in documents of variable length (between 20 and 44 pages) depending on the information and detailed exposition required in each one, including images in which the process of applying the technique was decomposed. To carry it out, the guidelines established by [23], [24] were followed, trying to achieve a suitable presentation for the type of document. In this sense, in order to simplify the process and following the recommendations of [25], images of machines, real and laboratory equipment were previously prepared, which facilitate the visualization and assimilation of the theoretical and practical concepts presented.

In addition, and according to the nature of each content, a different digital format was used. In the case of downloadable documents, the most appropriate standard for the distribution of this type of material was used, the PDF, which allows the inclusion of links, links, formulas, etc. that offered the possibility of printing only the parts that were considered most interesting.

Videos: the production of the videos involved in the first place making a synthesis of content that managed to make sense on its own, trying to reduce as much as possible the references of other possible resources. The recording was made with the help of a mobile phone camera. The capture program was incorporating the video and audio recorded in different tracks, which could be later edited if necessary. The last step was to create the video, exporting it to one of the typical formats for viewing on all types of devices. In this work, the program used for the layout and insertion of texts and audios was Imovie (version 2020), and they were exported to the high definition MP4 format.

Software: lastly, the presentation of the necessary software was included, which as a tool for this project facilitated practical and applied training, allowing the autonomous use of specialized free access software (XpowderX, JD Martín-Ramos, ISBN 84-6091497- 6, 2004).

In relation to evaluation, two different types were carried out at the PID, the first one the design evaluation, carried out by the Secretariat for Teacher Training, Innovation and Evaluation, 
Virtual environments of teaching-learning for training in experimental techniques. Innovation in multidisciplinary groups

Ma Paz Sáez-Pérez, Kerstin Kelert, Carlos Rodríguez-Navarro, Encarnación Ruiz Agudo, Aurelia Ibáñez Velasco, Carolina Cardell Fernández, María del Rosario Blanc García, Giuseppe Cultrone, Pedro Bel Anzue

with the support of the Teacher Training and Innovation Commission (Commission FIDO) that carried out the evaluation and selection of applications for all the calls included in this Plan and the second the evaluation of the derived products and the implementation of the project, carried out by the participating teaching team through the survey shown in Figure 2 [2.a (Design evaluation), 2.b (Process evaluation) and 2.c. (Product evaluation)].

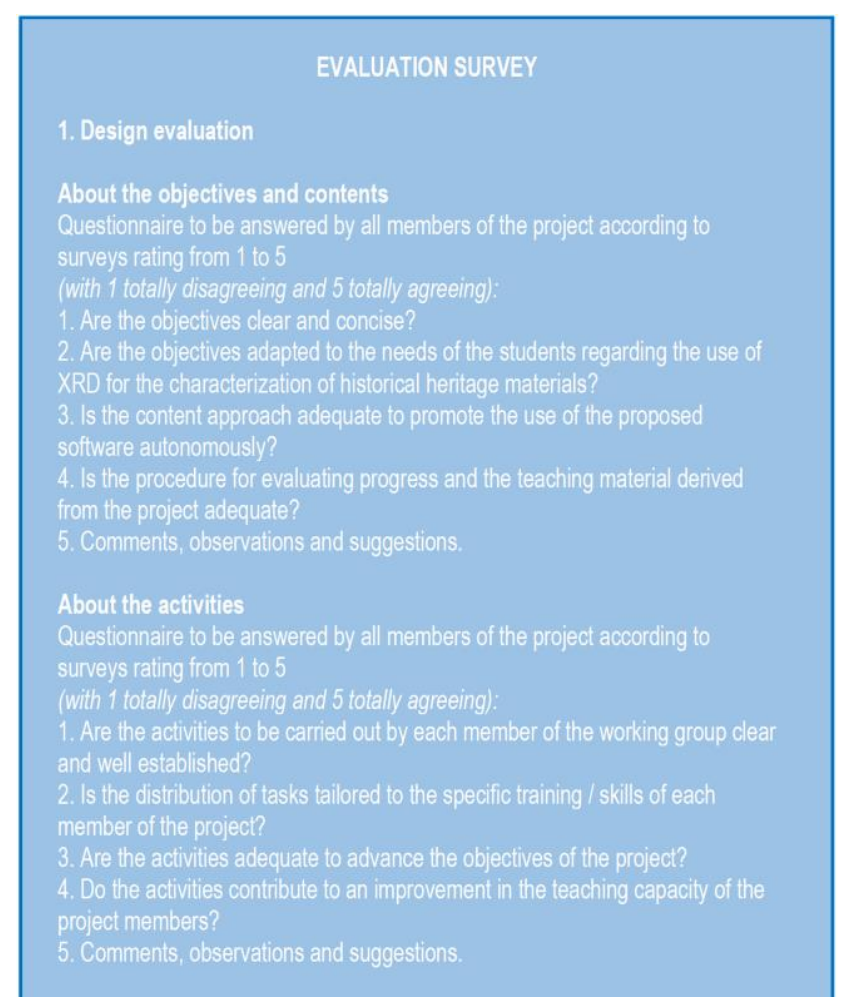

2.a Design evaluation

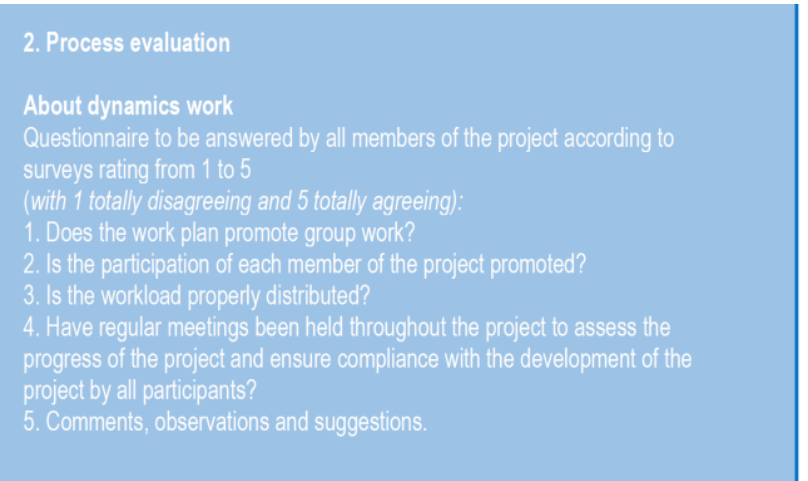

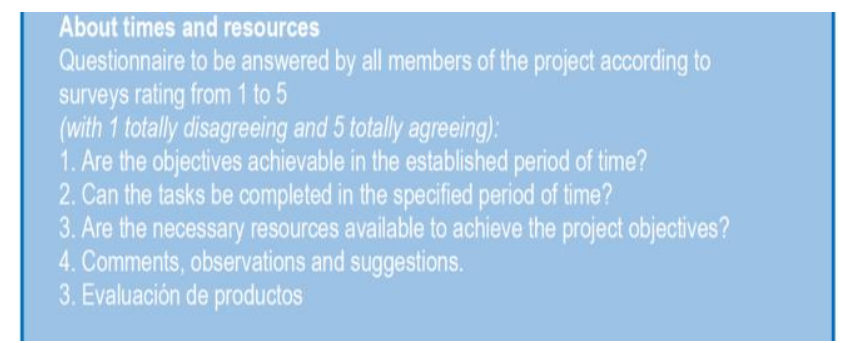

2.b Process evaluation

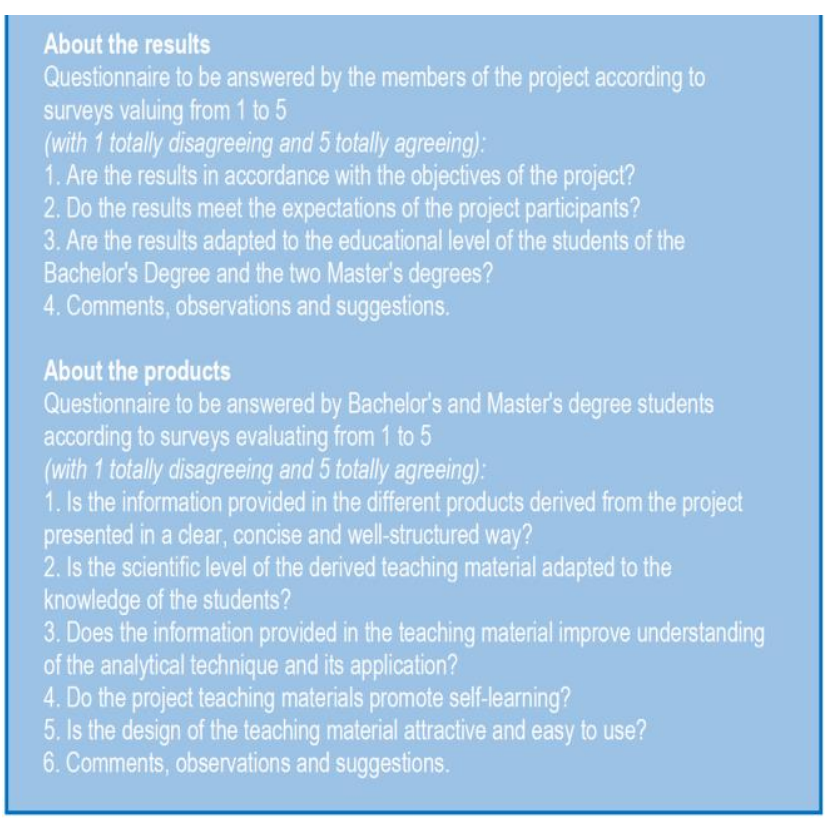

2.c Product evaluation

Fig. 2: PID evaluation survey

\section{RESULTS}

Regarding the resulting product, different views of the documents and educational material derived from this project are shown below (manual and PowerPoint with bilingual audio and video). Figures 3 to 6. 
Virtual environments of teaching-learning for training in experimental techniques. Innovation in multidisciplinary groups

Ma Paz Sáez-Pérez, Kerstin Kelert, Carlos Rodríguez-Navarro, Encarnación Ruiz Agudo, Aurelia Ibáñez Velasco, Carolina Cardell Fernández, María del Rosario Blanc García, Giuseppe Cultrone, Pedro Bel Anzue

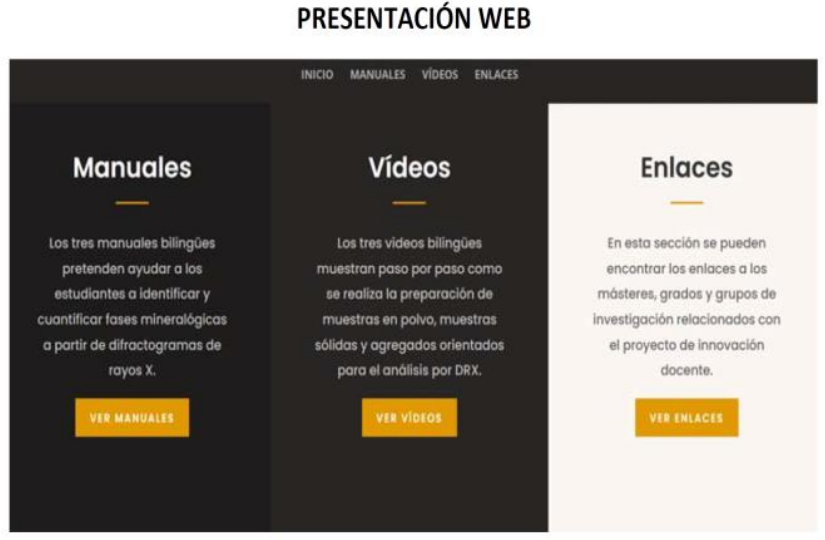

Fig. 3: PID product web page cover

The resulting material exposed in images aims to fill the existing gap in relation to the competencies identified for the application of analytical techniques, helping the student during the research period and future professional activities in the field of historical heritage.
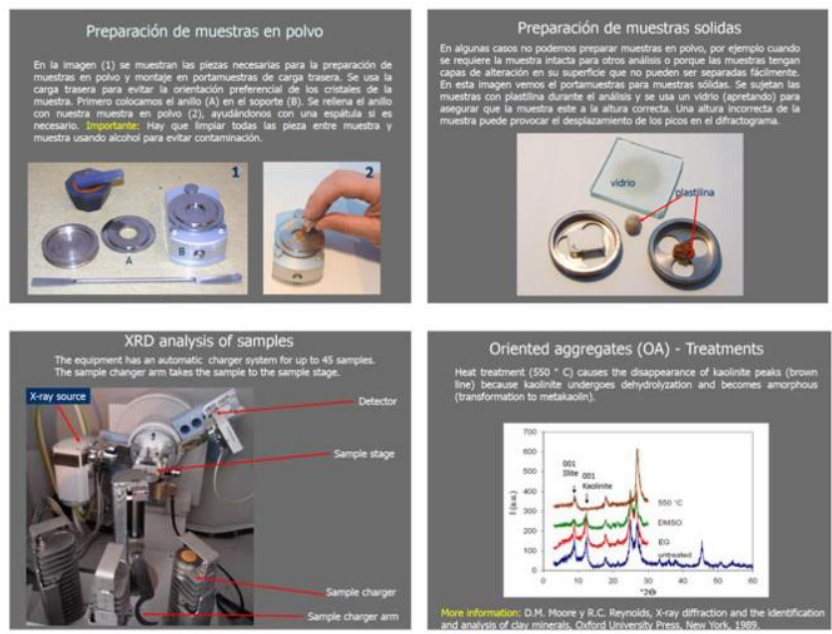

Fig. 4: Manual 1 in bilingual version. Sample preparation and analysis
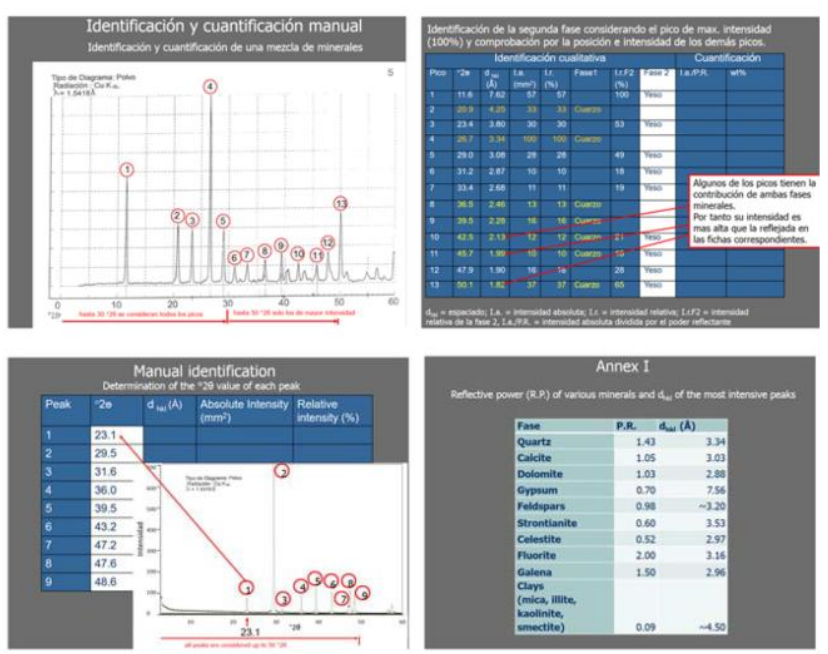

Fig. 5: Manual 2 in bilingual version. Manual identification and quantification (XRD Practices)

In addition, the use of the available documentation will allow each student to become familiar with the software at their own pace, self-evaluating the learning progress through the resources provided.
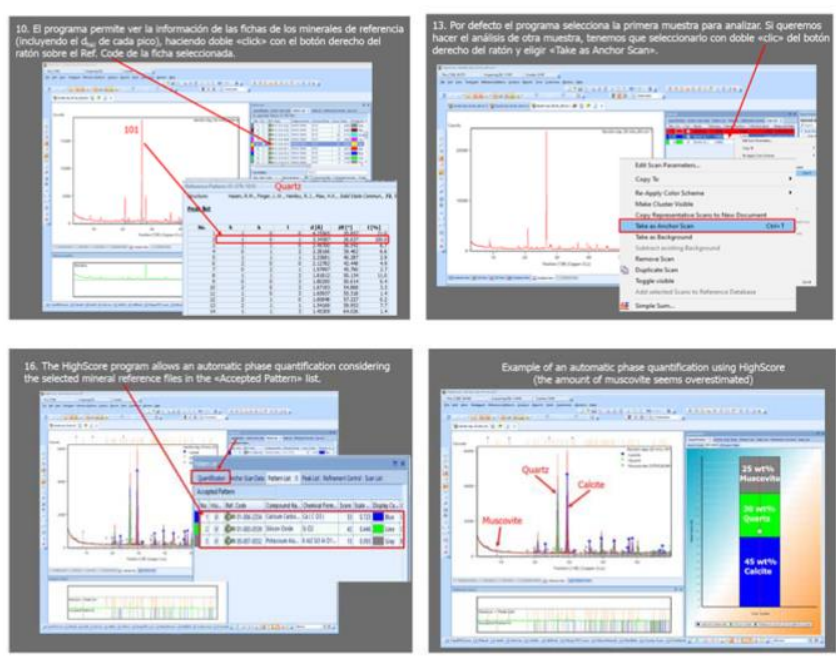

Fig. 6: Manual 3 in bilingual version. Identification and quantification using HighScore.

Finally, indicate that in relation to the expected results and according to previous experiences and research [26], [27], [28], in the case of students, it is expected to confirm that the use of the product resulting from the experience of

Advances in Building Education / Innovación Educativa en Edificación | ISSN: 2530-7940 |

http://polired.upm.es/index.php/abe

| Cod. 2103 | Septiembre - Diciembre 2021 | Vol. 5 № 3 | pp. 27/40 | 
teaching innovation does not It has taken away study time, increased their motivation to study the different subjects and has contributed to improving the teaching-learning process, in this modality through teaching videos.

In addition and specifically according to similar studies [20], the results of the PID applied to the teaching-learning process will favor the improvement of the following questions:

- Improvement of own knowledge for the development of practices

- Expansion of students' knowledge by studying new techniques used in the characterization of heritage, which otherwise they would not know in detail

- Getting in touch with the process of preparation and implementation of the analytical technique, which are not the object of study in the theory classes, or in any other subject of the degrees involved.

From the teaching point of view, it is expected to be able to confirm in the coming years the following benefits of the application of the product of the innovation project:

- The content is related to the acquisition of skills in direct contact with professional reality

- Clear objectives and activities to be carried out, possible to fulfill and that motivate adequately.

- Coherent and temporarily manageable stages of project development.

- Compliance with the Schedule.

- Helps and facilitates obtaining better results

\section{CONCLUSIONS}

The modalities of innovation supported by technological resources lead to new teaching processes that emphasize the active involvement of the student in the learning process, attention to skills and abilities and preparation to assume responsibilities in their professional field [8].

Similarly, the role of teaching staff also changes in an environment rich in technological resources. The teacher is no longer a source of all knowledge and begins to act as a teaching guide, accentuating his role as a guide and mediator, as well as standing out as a manager of resources, facilitating the use of the tools they need to explore and develop new knowledge and powers [29].

In this context, teachers must be involved in their preparation, which requires specific training in teaching techniques and methodologies, be aware of the necessary resources and software, use manuals and specific user guides that allow them to be an active participant, putting their knowledge and skills for the good result and effectiveness of the process assuming all this in a multidisciplinary team.

Furthermore, for the teacher, being an essential part of the process, it represents a new opportunity to learn from an innovative practice, performing teaching functions of the teaching professional through the approach of training needs, task planning, multidisciplinary teamwork, analysis systematic of the proposed activities and finally evaluation of the model and the results obtained.

For the student, and focused on their training through the development of competencies, it is intended to increase the level of knowledge and skills in a discipline (analytical technique) trying to achieve a high level of skill in that specific context, which in parallel is complemented with theoretical knowledge and its application to practical knowledge. In addition, the proposed teaching innovation and more specifically its 
implementation constitutes a means that allows the student to develop a more individual and flexible training, facilitating the conditions that allow meeting the needs related to the temporary arrangement, the combination of the working day and the study, the pace of learning, place, individual work, level of qualification, etc.

Realizada la práctica totalidad del proyecto, se confirma en línea con lo indicado por [25] que tratándose de actividades fáciles de implementar y totalmente replicables en cualquier área de conocimiento, hay que destacar que requieren de una cierta dedicación de tiempo por parte del profesorado, especialmente la actividad de elaboración de los vídeos y manuales y posteriormente su seguimiento y evaluación.

In turn, the result of the product produced in the PID includes all the competences and learning outcomes in the field of the degrees involved, in addition the material is available and serves to support teaching both for the staff directly involved and for any other interested party. in learning and knowing better the practical and competency concepts of the application of the technique.

This allows to conclude that the didactic material derived from this project will help the student in the acquisition of competences and in the performance of the required tasks (preparation of samples and analysis and interpretation of the XRD results) independently, respecting the rhythm of learning of each.

\section{ACKNOWLEDGMENTS}

This work has received a grant from the Master CiTPA, and is part of the Teaching Innovation Project "X-ray diffraction (XRD) Qualitative and quantitative analysis applied to historical heritage materials (Manual for students of the Master in Science and Technology in Heritage Architectural (CiTPA-Ugr), University Master's Degree in Architectural Rehabilitation (MARA-Ur) and Degree in Conservation and Restoration of Cultural Assets (Ugr) COD. 20-35 (Call for Teaching Innovation Projects and Good Practices of the FIDO UGR Plan 2020 -2022) and the Research Group RNM 0179 of the Junta de Andalucía.

\section{REFERENCES}

[1] Salinas, J. (2004). Innovación docente y uso de las TIC en la enseñanza universitaria RUSC. Universities and Knowledge Society Journal, 1, (1), septiembre-noviembre, pp.1-16.

[2] Martí, J.A., Heydrich, M., Rojas, M. Hernández, A. (2010). Aprendizaje basado en proyectos: una experiencia de innovación docente. Revista Universidad EAFIT, vol. 46, núm. 158, abril-junio, pp.11-21.

[3] Katz, L.G., Chard, S.C. (1989). Engaging children's minds: The project approach. Norwood, N.J: Ablex

[4] Cebrián, M. (2003). Enseñanza virtual para la innovación universitaria. Ed. Narcea.

[5] Macanchí Pico, M.L., Bélgica Marlene, O.C., Campoverde Encalada, M.A. (2020). Innovación educativa, pedagógica y didáctica. Concepciones para la práctica en la Educación Superior. Universidad y Sociedad, 12(1), pp. 396-403.

[6] Zabalza Beraza, M.A. (2012). El estudio de las "buenas prácticas" docentes en la enseñanza universitaria. Revista de Docencia Universitaria, 10(1), pp.105-122.

\section{Advances in Building Education / Innovación Educativa en Edificación | ISSN: 2530-7940 | http://polired.upm.es/index.php/abe \\ | Cod. 2103 | Septiembre - Diciembre 2021 | Vol. 5 № 3 | pp. 27/40 |}


[7] Gisbert, M., González, A.P., Jiménez, B., Ponce, C., Contijoch, M.T., Lladó, F., Guell, M., Adell, J., Nofre, E., Fabra, M. (1997). El docente y los entornos virtuales de enseñanzaaprendizaje. En: Cebrián [et al.]. Recursos tecnológicos para los procesos de enseñanza y aprendizaje, pp. 126-132).

[8] Salinas, J. (1997). Nuevos ambientes de aprendizaje para una sociedad de la información. Revista Pensamiento Educativo 20, pp. 81-104. PUC de Chile.

[9] Pérez i Garcías, A. (2002). Nuevas estrategias didácticas en entornos digitales para la enseñanza superior. En: Salinas, J., Batista, A. (coord.). Didáctica y tecnología educativa para una universidad en un mundo digital. Universidad de Panamá: Imprenta Universitaria.

[10] Fullan, M., Stilegelbauer, S. (1991). The New Meaning of Educational Change. Londres: Casell.

[11] Rhodes, D. (1994). Sharing the vision: creating and communicating common goals, and understanding the nature of change in education. En: Kearsley, G., Lynch, W. (ed.). Educational Technology. Leadership Perspectives. Englewood Cliffs (NJ): Educational Technology Publications

[12] Kofman, F., Senge, P.E. (1993). Communities of commitment: The heart of learning organizations. Organizational Dynamics, 22(3), pp. 5-23.

[13] Fullan, M. (2002). Liderar en una cultura de cambio. Barcelona: Octaedro.

[14] Bueno García, C., Gil Pérez, J.J. (2007). Web docente: estructura y conceptos básicos de gestión eficaz. Revista interuniversitaria de formación del profesorado, 21 (1), pp. 37-50.
[15] Plan de formación e innovación docente 2020-2022. Plan FIDO UGR Unidad de Calidad e innovación docente y prospectiva. Universidad de Granada.

[16] Proyecto de Innovación Docente (PID). Difracción de Rayos X (DRX) - Análisis Cualitativo y Cuantitativo aplicados a los materiales del patrimonio histórico (Manual para estudiantes del Máster en Ciencia y Tecnología en Patrimonio Arquitectónico (CiTPA-UGR), Máster Universitario en Rehabilitación Arquitectónica (MARA-UGR) y del Grado en Conservación y Restauración de Bienes Culturales (UGR))

[17] Feisel, L.D., Rosa, A.J. (2005). The Role of the Laboratory in Undergraduate Engineering Education. Journal of Engineering Education, 94(1), pp. 121-130. http://dx.doi: 10.1002/j.21689830.2005.tb00833.x

[18] Marcelo, C., Parrilla, A., Mingorance, P., Estebaranz A., Sánchez, M.V., Llinares, S. (1991). El estudio de caso en la formación del profesorado y la investigación didáctica. Sevilla: Secretariado de Publicaciones de la Universidad.

[19] Marín Díaz, V., Reche Urbano, E., Maldonado Berea, G.A. (2013). Ventajas e inconvenientes de la formación online. Revista Digital de Investigación en Docencia Universitaria (RIDU), 7(1), pp. 33-43.

[20] Estebaranz, J.J., Távara Mendoza, L. (2014). Teaching innovation in engineering: a students and teachers' learning integration programme. Revista Digital de Investigación en Docencia Universitaria 8(1).

[21] Caballero Míguez, G., Garza Gil, M.D. (2012). Innovando la docencia superior en Economía: trabajo cooperativo y elaboración 
participativa de contenidos. Revista de Docencia Universitaria, 10(2), pp. 319-327.

[22] Rebolloso Fuentes, M.M., Ramírez Alvarez, M., Gil Montoya, C., Gil Montoya, M.D. (2008). Experiencias de aprendizaje cooperativo en Ingeniería. (2008).

[23] Speakman, M.K., Sayers, P. (2016) Evaluating PowerPoint Presentations: A Retrospective Study Examining Educational Barriers and Strategies. Nursing Education Perspectives, vol. 37, no1, pp. 28-31. doi: 10.5480/14-1418

[24] Hashemi, M., Azizinezhad, M., Farokhi, M. (2012). Power Point as an innovative tool for teaching and learning in modern classes. Procedia - Social and Behavioral Sciences, 31, pp. 559-563. doi: 10.1016/j.sbspro.2011.12.103

[25] Zabalza Bribián, I., Peña Pellicer, B., Llera Sastresa, E.M., Usón Gil, S., Martínez Gracia, A., Romeo Giménez, L.M. (2018). Preparation of teaching videos as RLO for its integration in an OCW course on basic fundamentals of thermodynamics and thermal engineering. Jornadas Innovación Docente 2017: Innovación docente y aprendizaje: experiencias y retos pp. 39-44.

[26] Carrascal Domínguez, S., María de Vicente, A., Sierra Sánchez, J. (2020). Transformación e innovación educativa durante la crisis del COVID-19. Estilos y modelos de enseñanza y aprendizaje. Revista Estilos de Aprendizaje / Journal of Learning Styles 13, pp.1-4.

[27] Moreno-Correa, S.M. (2020), La innovación educativa en los tiempos del Coronavirus. Salutem Scientia Spiritus 6(1), pp.14-26.

[28] Ramírez-Montoya, M.S. (2020). Transformación digital e innovación educativa en Latinoamérica en el marco del CoVld-19. Campus Virtuales, 9(2), pp.123-139.

[29] Salinas, J. (1998). Redes y desarrollo profesional del docente: entre el dato serendipity y el foro de trabajo colaborativo. Profesorado 2 (1). Universidad de Granada. <http://www.uib.es/depart/gte/docente.html>. 